\title{
The Influence of Propionate on the Spectrum of Short-Chain Fatty Acids in Cervical Cells During Dis- and Neoplastic Transformation
}

\author{
Kayukova Elena ${ }^{1,}{ }^{*}$, Belokrinitskaya Tatyayna ${ }^{2}$, Sholokhov Leonid $^{3}$, Tereshkov Pavel $^{4}$, \\ Khyshiktuev Bair ${ }^{5}$ \\ ${ }^{1}$ Department of Oncology, Chita state Medical Academy, Chita, Russia \\ ${ }^{2}$ Department of Obstetrics and Gynecology, Chita State Medical Academy, Chita, Russia \\ ${ }^{3}$ Laboratory of Physiology and Pathology of the Endocrine System, Scientific Centre for Family Health and Human Reproduction Problems, \\ Irkutsk, Russia \\ ${ }^{4}$ Laboratory of Experimental and Clinical Biochemistry and Immunology, Chita State Medical Academy, Chita, Russia \\ ${ }^{5}$ Management Department, OOO «Medicom», Moscow, Russia
}

Email address:

elena_pochta22@mail.ru (K. Elena)

*Corresponding author

\section{To cite this article:}

Kayukova Elena, Belokrinitskaya Tatyayna, Sholokhov Leonid, Tereshkov Pavel, Khyshiktuev Bair. The Influence of Propionate on the Spectrum of Short-Chain Fatty Acids in Cervical Cells During Dis- and Neoplastic Transformation. International Journal of Biomedical Science and Engineering. Vol. 7, No. 1, 2019, pp. 20-25. doi: 10.11648/j.ijbse.20190701.14

Received: April 5, 2019; Accepted: May 29, 2019; Published: June 18, 2019

\begin{abstract}
Introduction. There is some data of the short-chain fatty acids (SCFA) participation in cancerogenesis. The cervical cancer is an "ideal" model for determining the molecular mechanisms underlying the development of cancer. The aim of study was to estimate the influence of propionate on the spectrum of SCFA in cervical cells during dis- and neoplastic transformation. Materials and methods of research. Materials of the study - cervical biopsy verified morphologically. Study groups: IA - the focus of the pretumor lesion of cervix; IB - paradisplastic cells; IIA - locus of cervical cancer; IIB paraneoplastic cells. The spectrum of fatty acids was analyzed before, after 24 hours incubation with $50 \mu \mathrm{mol} / 1$ propionic acid by the gas chromatography method. Methods of nonparametric statistics the Mann-Whitney test were used. Differences were considered statistically significant at $p<0.05$. Results of the study. The incubation of cervical cancer cells with propionate leads to an increase the level of propionate and butyrate. The incubation of "precancer", paraneoplastic and paradisplastic cells leads to an increase the levels of isobutyric, valeric and caproic acids against the background of a significant drop in the concentration of propionate and butyrate. Conclusion. It can be concluded that the effect of propionate on the metabolism of fatty acids in the cervical epithelium of the studied samples is multidirectional and depends on the cell type. The dates indicate the modifications of SCFA in the cervical carcinogenesis.
\end{abstract}

Keywords: Cancerogenesis, Cervical Cancer, Short Chain Fatty Acid

\section{Introduction.}

Cervical cancer is a long and staged oncological disease based on malignant transformation of exocervix and endocervix cells. From the perspective of oncogenesis research malignization of cervical epithelium is viewed as an «ideal» model to study molecular mechanisms provoking the development of oncological diseases. It were the cervical cancer cells (HeLa-cells) obtained as early as 1951 that were the first human "immortal" cells still being used for the research of biology of many diseases [1].

Currently there is no unified theory of cervical oncogenesis. Literature sources describe several ethiopathogenetic variants of the development of this disease: 
viral, bacterial, immunological, hormonal, and alterational. However, regardless of the trigger nature, further life of the cell is determined by the following processes: metabolic reprograming, proliferation, differentiation, apoptosis, cell cycle kinetics, and necrosis. It is known that the state of tumor cell biological membrane and its fatty acid composition potentiate the main elements of carcinogenesis. [2-5].

Recently data on participation of short-chain fatty acids (SCFA) in tumor growth have appeared in literature; they are viewed as metabolic by products of microorganisms. Only some information concerning SCFA metabolism peculiarities was found [6].

Earlier we determined that SCFA deficiency was observed in tumorous and dysplastic cervical epithelium cells. It was the most obvious in nidus of dysplasia and neoplasia [7, 8], since SCFA were used inter alia for synthesis of higher fatty acids in the tumor tissue.

\section{Aim of the Research}

The Aim of the Research is to estimate the influence of propionate, one of the SCFAs, in vitro, on the SCFA profile of cervical epithelium tissue lipids in premalignancies and neoplasia of exocervix, in order to get more extended data on interconversion of SCFAs in carcinogenesis.

\section{Materials and Methods of Research}

Nonrandomized controlled prospective study was performed. It included 58 women who were examined and treated in the Zabaikalye Territorial Oncology Center. The average age of the patients was $38 \pm 8.26$ years. All patients were informed about the study and gave their written consent to participate. The study was compliant with the principles of WMA Declaration of Helsinki, 1964, rev. 2013 and was performed with consent of the Local Ethics Committee of Chita State Medical Academy [9].

Control group samples were collected from 18 apparently healthy women aged from 28 to 48 years ( $34.5 \pm 6.5$ years), under dispensary observation because of non-tumor exocervix pathology treated earlier. They were informed about the study design, and gave informed consent to participate. Integrity of the cervical epithelium was confirmed morphologically.

Cervical tissue fragments received by target biopsy or intraoperatively under morphological control served as samples for the research. According to histological examination, each tissue fragment was divided into two loci: A - diseased area, Б (B) - tissue showing no signs of dysplastic and neoplastic transformation. The patients were divided into three clinical groups: I - patients with cervical premalignancies $(20$ - grade III cervical intraepithelial neoplasia), II - cervical cancer (20 - histologically squamous cell cancer, stage $0-\mathrm{Ib}$ ), control group - healthy women (18).

In order to get cell-rich fluid biopsy, samples were pulverized and homogenized in Gentle MACS Dissociator (Miltenyi Biotec $\mathrm{GmbH}$, Germany) using $\mathrm{C}$ type tubes, and Tumor Dissociation Kit reagents (Miltenyi Biotec $\mathrm{GmbH}$, Germany) in compliance with the procedure. The obtained cell-rich fluid was filtered through capronic filter with the mesh size of $30 \mu \mathrm{m}$ (Miltenyi Biotec $\mathrm{GmbH}$, Germany). The cells were washed by autoMACS Rinsing Solution (Miltenyi Biotec $\mathrm{GmbH}$, Germany). The cells were counted by FC500 flow cytofluorometer (Beckman Coulter, USA) using FLOW-COUNT Fluorospheres (Beckman Coulter, USA).

The amount of SCFAs in washed cell-rich fluid was determined by procedure developed by Ardatskaya M.D. (2004) and modified by us. It comprised two stages: sample preparation, and gas-liquid chromatography [10].

SCFA extraction was performed as follows: diethyl ether and cell suspension were mixed in equal amounts, then 0.50 $\mathrm{ml}$ of $50.0 \%$ sulfuric acid and internal standard $(\alpha, \alpha-$ dimethyl-butanoic acid) were added. The mixture was shaken vigorously for 10 minutes and centrifuged at $3000 \mathrm{rpm}$ for the same time. The supernatant was evaporated to dryness, dissolved by hexane and then analyzed by «Кристалл2000M (Crystal-2000M)» chromatograph (Russia). The following acids were detected: $\mathrm{C}_{3: 0}-$ propionic acid, $\mathrm{C}_{4: 0}-$ butyric acid, iso $\mathrm{C}_{4: 0}$ - isobutyric acid, $\mathrm{C}_{5: 0}$ - valerianic acid, and $\mathrm{C}_{6: 0}-$ capronic acid.

Statistical data processing was performed by «BIOSTAT» software. The results were presented as a median, 25th and 75th percentile. Methods of nonparametric statistics using the Wilcoxon signed-rank test for paired measurements and Mann-Whitney $U$ test for the control group were used. The differences were considered statistically significant at $\mathrm{p}<0.05$.

\section{Results of Research}

Cervical epithelium cells regardless of pathology type (neoplasia or precancer), their localization (tumor nidus or distal cells), and incubation conditions (with propionic acid or without propionic acid) showed the total deficiency of SCFA, and the deficiency grew in the premalignancy nidus and paraneoplastic cells under the influence of propionate (Figure 1).

In the presence of propionic acid cervical cancer cells showed increased share of short-chain analogs - 1.5 times higher at the expense of both even-numbered and oddnumbered fatty acids; however, their level never reached the control value $(\mathrm{p}<0.001)$.

SCFA content in paradysplastic biopsy material after incubation with $\mathrm{C}_{3: 0}$ increased only by $6 \%$, mainly at the expense of analogs with an even number of carbon atoms $(\mathrm{p}<0.001)$. 


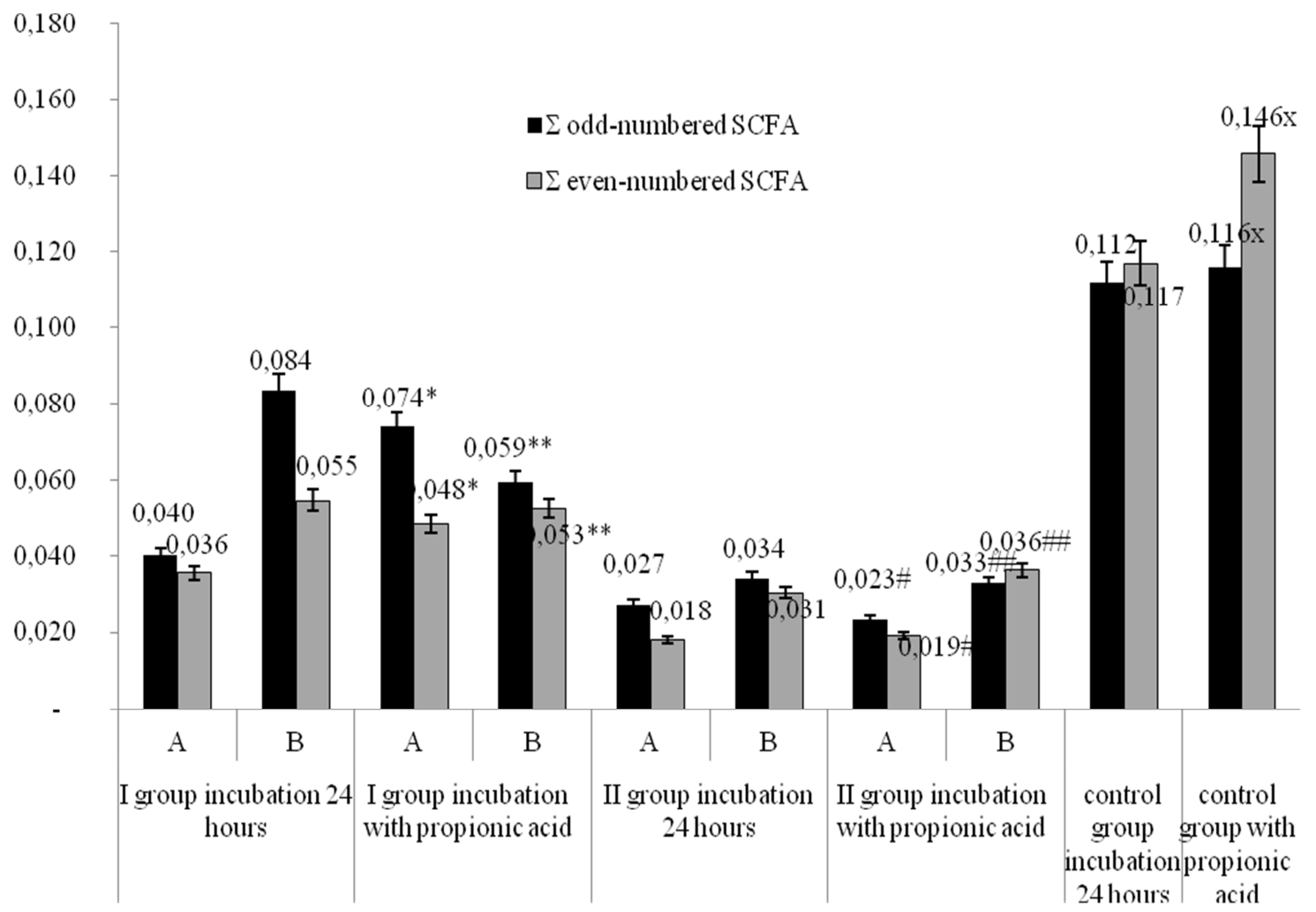

*, **, \#, \#\#, $\mathrm{x}, \mathrm{xx}-$ statistical significance of parameters from the corresponding subgroups incubated with propionic acid and without propionic acid (p<0,001)

Figure 1. Total SCFA Content (ng/cell) in Cervical Cancer Cells of Different Localization at Dysplastic and Neoplastic Transformations Depending on the Conditions of Incubation.

Cervical epithelium cells of both groups regardless incubation conditions (with propionic acid or without propionic acid) showed total deficiency of SCFA, while this deficiency grew in the premalignancy nidus and paraneoplastic cells under the influence of propionate.

The detailed changes of SCFA pool in the cervical epithelium cells depending on conditions of incubation are shown in the table 1.

In the «premalignancy» group the level of $\mathrm{C}_{3: 0}, \mathrm{C}_{4: 0}$ statistically did not differ from localization of cells. After incubation with propionate, concentration of the latter both in premalignancy locus and in paradysplastic cells decreased by
$27.2 \%$ and $30 \%$ correspondingly $(p<0.02)$. The share of the remaining SCFA $\left(\mathrm{iC}_{4: 0}, \mathrm{C}_{5: 0}, \mathrm{C}_{6: 0}\right)$ in the cells of this group grew, but did not reach the control values $(\mathrm{p}<0.001)$.

In cervical cancer biopsy materials after incubation with $\mathrm{C}_{3: 0}$ changes of SCFA pool were caused only by increasing concentration of propionate itself, and butyrate by 3.2 and 2 times correspondingly $(\mathrm{p}<0.02)$.

In paraneoplastic tissue fragments, under the influence of propionic acid, their level decreased by $40.6 \%$ each $(\mathrm{p}<0.02)$, while the share of isobutyrate, valeriate and capronoate increased by $54.5 \%, 50 \%$, and $50 \%$ correspondingly $(\mathrm{p}<0.02)$.

Table 1. SCFA Content (ng/cell) in Cervical Cells of Different Localization at Dysplastic and Neoplastic Transformations Depending on the Conditions of Incubation.

\begin{tabular}{|c|c|c|c|c|c|}
\hline \multirow{2}{*}{$\begin{array}{l}\text { group } \\
\text { SCFA }\end{array}$} & \multirow{2}{*}{ Control $(n=25)$} & \multicolumn{2}{|l|}{ I group } & \multicolumn{2}{|l|}{ II group } \\
\hline & & $\operatorname{locus} A(n=35)$ & locus B $(n=35)$ & $\operatorname{locus} A(n=45)$ & $\operatorname{locus} A(n=45)$ \\
\hline \multicolumn{6}{|c|}{ incubation 24 hours } \\
\hline $\mathrm{C}_{3: 0}$ & $0,060(0,049 ; 0,089)$ & $0,022(0,022 ; 0,023)$ & $0,022(0,016 ; 0,029)$ & $0,019(0,09 ; 0,058)$ & $0,074(0,035 ; 0,120)$ \\
\hline $\mathrm{C}_{4: 0}$ & $0,026(0,021 ; 0,039)$ & $0,010(0,009 ; 0,010)$ & $0,010(0,007 ; 0,012)$ & $0,08(0,004 ; 0,025)$ & $0,032(0,015 ; 0,053)$ \\
\hline $\mathrm{iC}_{4: 0}$ & $0,059(0,045 ; 0,067)$ & $0,005(0,004 ; 0,006)$ & $0,013(0,013 ; 0,014)$ & $0,013(0,008 ; 0,018)$ & $0,011(0,006 ; 0,020)$ \\
\hline $\mathrm{C}_{5: 0}$ & $0,032(0,025 ; 0,037)$ & $0,005(0,004 ; 0,006)$ & $0,012(0,011 ; 0,013)$ & $0,011(0,007 ; 0,016)$ & $0,010(0,006 ; 0,018)$ \\
\hline $\begin{array}{l}\mathrm{C}_{6: 0} \\
\text { incubat }\end{array}$ & $\begin{array}{l}0,112(0,089 ; 0,150) \\
\text { vith propionic acid }\end{array}$ & $0,003(0,002 ; 0,004)$ & $0,007(0,007 ; 0,008)$ & $0,007(0,004 ; 0,010)$ & $0,006(0,003 ; 0,011)$ \\
\hline $\mathrm{C}_{3: 0}$ & $0,044 x(0,036 ; 0,063)$ & $0,016 \#(0,016 ; 0,017)$ & $0,016 \# \#(0,012 ; 0,020)$ & $0,062 *(0,033 ; 0,106)$ & $0,044 * *(0,022 ; 0,064)$ \\
\hline $\mathrm{C}_{4: 0}$ & $0,019 \times(0,016 ; 0,027)$ & $0,007 \#(0,007 ; 0,007)$ & $0,007 \# \#(0,005 ; 0,009)$ & $0,027 *(0,014 ; 0,046)$ & $0,019 * *(0,010 ; 0,028)$ \\
\hline $\mathrm{iC}_{4: 0}$ & $0,082 \times(0,062 ; 0,099)$ & $0,008 \#(0,006 ; 0,009)$ & $0,019 \# \#(0,018 ; 0,020)$ & $0,013(0,008 ; 0,018)$ & $0,017 * *(0,011 ; 0,028)$ \\
\hline $\mathrm{C}_{5: 0}$ & $0,072 \times(0,056 ; 0,087)$ & $0,007 \#(0,005 ; 0,008)$ & $0,017 \# \#(0,016 ; 0,018)$ & $0,011(0,007 ; 0,016)$ & $0,015 * *(0,009 ; 0,025)$ \\
\hline $\mathrm{C}_{6: 0}$ & $0,045 \times(0,034 ; 0,054)$ & $0,004 \#(0,003 ; 0,005)$ & $0,010 \# \#(0,010 ; 0,011)$ & $0,007(0,004 ; 0,010)$ & $0,009 * *(0,006 ; 0,015)$ \\
\hline
\end{tabular}

$*, * *, \#, \# \#, \mathrm{x}, \mathrm{xx}$ - statistical significance of parameters from the corresponding subgroups incubated with propionic acid and without propionic acid $(\mathrm{p}<0,001)$ 
In order to exclude possible influence of conditions of incubation and to estimate real influence of propionate on SCFA metabolism in cervical cells, we performed comparative study of their profile in the researched clinical groups before and after the incubation, in the presence of propionic acid and without propionic acid (Figure 2).

Under the influence of $\mathrm{C}_{3: 0}$ in cervical cancer biopsy materials the pool of odd-numbered SCFA increased by $80 \%$, as opposed to precancer locus and paraneoplastic cells, where the content of short-chain analogs was reduced regardless of the amount of carbon atoms: by $21.3 \%$ and $20.6 \%$ - for oddnumbered SCFA and by $8.6 \%$ and $9.5 \%$ - for even-numbered SCFA in conditionally healthy cells of the "cancer" group and premalignancy nidus correspondingly $(\mathrm{p}<0.001)$.

In cells of paradysplastic localization after incubation with propionic acid the share of odd-numbered SCFA decreased by $11 \%(\mathrm{p}<0.001)$.

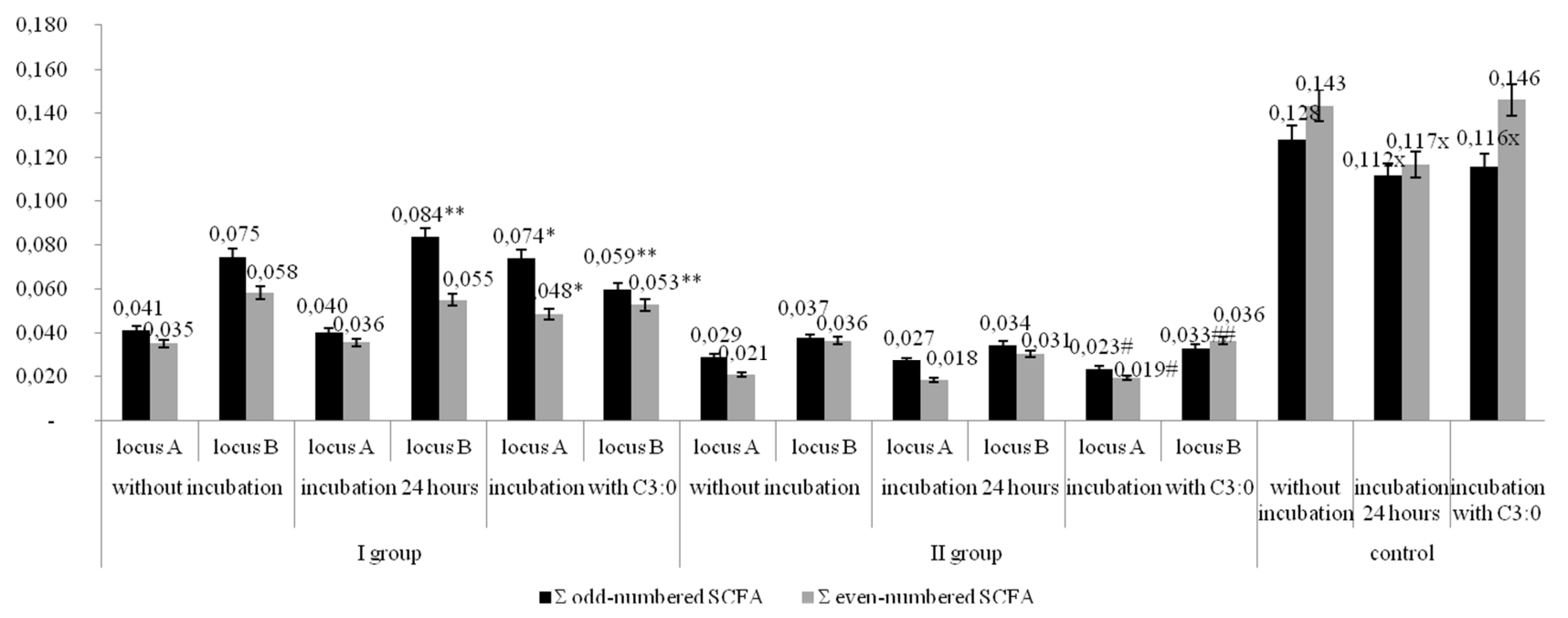

*, **,\#,\#, $\mathrm{x}, \mathrm{xx}$ - statistical significance of parameters from the corresponding subgroups incubated with propionic acid and without propionic acid $(\mathrm{p}<0,001)$

Figure 2. SCFA Structure (ng/cell) in Cervical Cells at Dysplastic and Neoplastic Transformations before and after Incubation with Propionic Acid and without Propionic Acid.

Under the influence of $\mathrm{C}_{3: 0}$ in cervical cancer biopsy materials the pool of odd-numbered SCFA increased by $80 \%$, as opposed to precancer locus and paraneoplastic cells. In cells of paradysplastic localization after incubation with propionic acid the share of odd-numbered SCFA decreased by $11 \%(\mathrm{p}<0.001)$.

The detailed changes of SCFA profile in cervical epithelium cells depending on the pathology type, distance from the tumor nidus and conditions of incubation are shown in the figure 3.

In cervical cancer locus during 24-hour incubation all SCFA showed only the tendency of decreased concentration. After incubation of cervical cancer cells with $\mathrm{C}_{3: 0}$ increase of propionic acid and butyric acid pool by more than 2 times $(\mathrm{p}<0.001)$ was registered.

It was observed in paraneoplastic cells during incubation without propionate addition that the levels of $\mathrm{C}_{3: 0}, \mathrm{C}_{4: 0}$ increased by 1.9 and 1.8 times correspondingly $(\mathrm{p}<0.001)$ against the background of decreased share of $\mathrm{iC}_{4: 0}, \mathrm{C}_{5: 0}$, $\mathrm{C}_{6: 0}$ by $21.4 \%, 23.1 \%$ and $25 \%$ correspondingly $(\mathrm{p}<0.001)$. In conditions of incubation with propionate the opposite situation was observed: increased pool of isobutyric, valerianic, and capronic acid by $21.4 \%, 15.4 \%$ and $12.5 \%$ correspondingly against the background of decreased concentration of propionate and butyrate approximately by $30 \%$ each $(\mathrm{p}<0.001)$.

In the premalignancy nidus after incubation of cells with $\mathrm{C}_{3: 0}$ deficiency of propionate and butyrate by $30 \%$ was determined for each SCFA $(\mathrm{p}<0.001)$, the levels of $\mathrm{iC}_{4: 0}, \mathrm{C}_{5: 0}$ increased by $14 \%$ and $40 \%$ correspondingly ( $p<0.001$ ); also a constant level of $\mathrm{C}_{6: 0}$ was observed. Similar SCFA profile was observed in cells of paradysplastic localization with the exception of capronic acid, which increased by $42.9 \%$ after incubation with $\mathrm{C}_{3: 0}(\mathrm{p}<0.001)$.

I group

locus $\mathrm{A}$

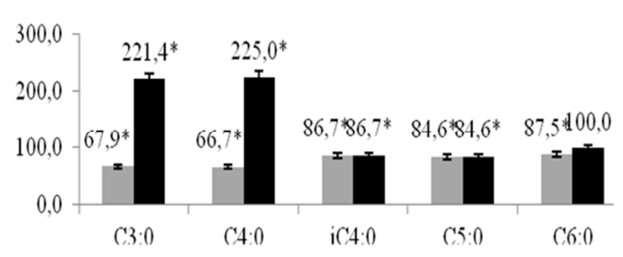

locus B

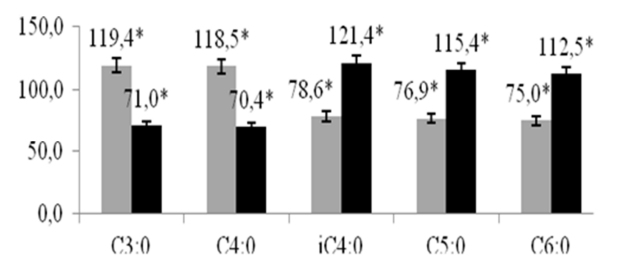


II group

locus A

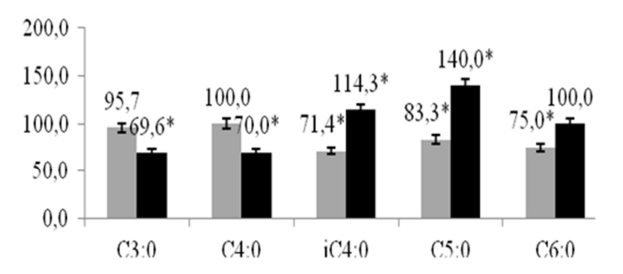

locus B

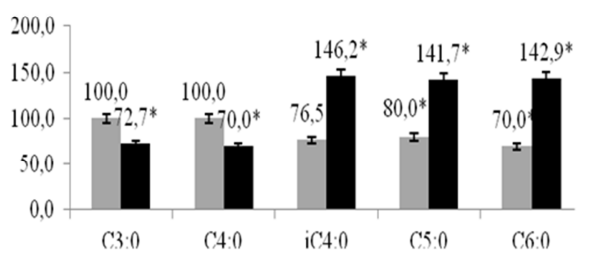

Control

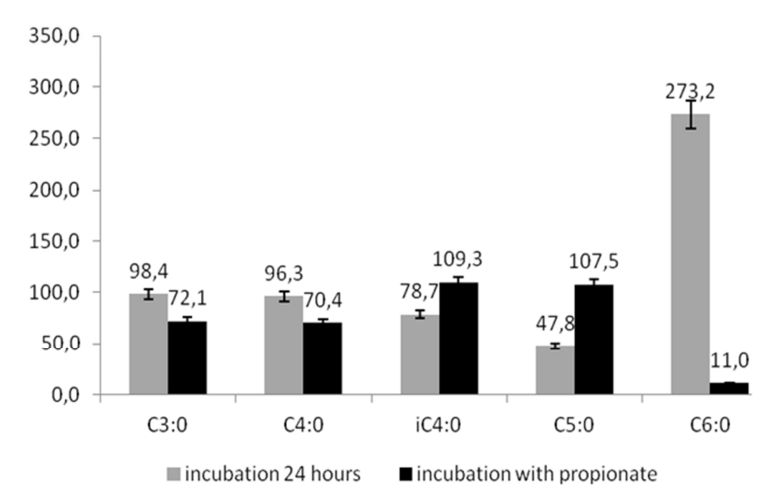

* - statistical significance of parameters from the corresponding subgroups incubated with propionic acid and without propionic acid ( $<<0,001$ )

Figure 3. Change of SCFA Pool (\%) in Cervical Cells of Different Localization at Dysplastic and Neoplastic Transformation sunder the Influence of Propionate.

The incubation of cervical cancer cells with propionate leads to an increase the level of propionate and butyrate. The incubation of "precancer", paraneoplastic and paradisplastic cells leads to an increase the levels of isobutyric, valeric and caproic acids against the background of a significant drop in the concentration of propionate and butyrate.

\section{Discussion}

The analyzed Russian and foreign literature did not contain any data concerning changes of SCFA metabolism in tumor tissue. We can assume that excess of $\mathrm{C}_{3: 0}$ and $\mathrm{C}_{4: 0}$ in cervical cancer lesion after incubation with propionate is caused not only by its exogenous inflow, but also by interconversions of SCFA, oxidation reaction of even-numbered (for butyric acid) and odd-numbered (for propionic acid) fatty acids, as well as by the possibility of preliminary formation of $\mathrm{C}_{3: 0}$ in tumor tissue from glucose. Such changes in malignant tissue are possibly caused by high energy status of tumor cells [11-15].

Moreover, in order to preserve liquid crystalline structure of its membranes against the background of deficiency of polyunsaturated fatty acids, cancer cells possibly initiate synthesis of $\alpha$-methylstearinic acid from propionate, according to the theory of Khyshiktuev B.S. (1995). We also found this compound in cervical cancer tumor growth [8].

\section{Conclusion}

Thus, the influence of propionate on SCFA metabolism in cervical epithelium of the studied samples is various and depends on the type of the cell: increased levels of $\mathrm{C}_{3: 0}$ and $\mathrm{C}_{4: 0}$; are observed in cancer cells, while in paraneoplastic and paradysplastic areas share of isobutyric, valerianic, and capronic acid is increased with considerable decrease of propionate and butyrate concentrations.

\section{Conflict of Interest}

The authors of the article declare no conflict of interest.

The authors of the article certify the original work, he manuscript has not previously been published and is not currently being considered for publication elsewhere.

The study was performed with the state financial support from the RF presidential fellowship for young Russian scientists MK-6143.2018.7.

Compliance with the Ethical Principles

The study was compliant with the principles of WMA Declaration of Helsinki, 1964, rev. 2013 and was performed under consent of the Local Ethics Committee of Chita State Medical Academy. All patients gave written consent to participate in the research.

\section{References}

[1] Beskow LM, (2016), Lessons from HeLa Cells: The Ethics and Policy of Biospecimens. Annu Rev Genomics Hum Genet, 17: 395-417. 
[2] Wang G, Yu Y, Wang YZ, Wang JJ, Guan R, Sun Y, Gao F, Shi J, Fu XL, (2019), Role of SCFAs in gut microbiome and glycolysis for colorectal cancer therapy. J Cell Physiol, doi: $10.1002 / \mathrm{jcp} .28436$.

[3] Zhao L, Bin S, He HL, Jang MY, Pu YC, Gao CH, Wang H, Wang BL, (2018), Sodium butyrate increases P-gp expression in lung cancer by upregulation of STAT3 and mRNA stabilization of ABCB1. Anticancer Drugs, 3: 227-233.

[4] Li L, Ma L, Fu P, (2017), Gut microbiota-derived short-chain fatty acids and kidney diseases. Drug Des Devel The, 11: 3531-3542.

[5] Mikó E, Kovács T, Sebő É, Tóth J, Csonka T, Ujlaki G, Sipos A, Szabó J, Méhes G, Bai P, (2019), Microbiome-Microbial Metabolome-Cancer Cell Interactions in Breast CancerFamiliar, but Unexplored. Cells, 8(4). doi: 10.3390/cells8040293.

[6] Heers H, Stanislaw J, Harrelson J, Lee MW, (2018), Valproic acid as an adjunctive therapeutic agent for the treatment of breast cancer. Eur J Pharmacol, 835: 61-74.

[7] Kayukova E, Tereshkov P, (2015), The short chain fatty acid spectrum of cervical dysplasia and cancer cells. Sovremennye problemy nauki i obrazovaniya, 2-1. URL: http://scienceeducation.ru/ru/article/view?id=18999.

[8] Kayukova E, Belokrinitskaya T, Tereshkov P, (2019), The fatty acid status of the cervical cells during dis-and neoplastic transformation. Fundamental and clinical medicine, 3 (3): 3544.
[9] World Medical Association Declaration of Helsinki: ethical principles for medical research involving human subjects (2013). JAMA, 310: 2191-2194.

[10] Minushkin O, Ardatskaya MD, (2004), Opportunities and prospects for the study of short-chain fatty acids in the pathology of the gastrointestinal tract on the example of diseases of the intestine and organs of the hepatobiliary system. Clinical laboratory diagnosis, 2: 19-36.

[11] Kanikarla-Marie P, Kopetz S, Hawk ET, Millward SW, Sood AK, Gresele P, Overman M, Honn K, Menter DG, (2018), Bioactive lipid metabolism in platelet "first responder" and cancer biology. Cancer Metastasis Rev, 37(2-3): 439-454.

[12] Yi M, Li J, Chen S, Cai J, Ban Y, Peng Q, Zhou Y, Zeng Z, Peng S, Li X, Xiong W, Li G, Xiang B, (2018), Emerging role of lipid metabolism alterations in Cancer stem cells. J Exp Clin Cancer Res, 37(1). doi: 10.1186/s13046-018-0784-5.

[13] Nakagawa H, Hayata Y, Kawamura S, Yamada T, Fujiwara N, Koike K, (2018,) Lipid Metabolic Reprogramming in Hepatocellular Carcinoma. Cancers (Basel), 10(11). doi: 10.3390/cancers10110447. Review.

[14] Sivaprakasam S, Prasad PD, Singh N, (2016), Benefits of short-chain fatty acids and their receptors in inflammation and carcinogenesis, 164: 144-51.

[15] Pope ED, Kimbrough EO, Vemireddy LP, Surapaneni PK, Copland JA 3rd, Mody K, (2019), Aberrant lipid metabolism as a therapeutic target in liver cancer. Expert Opin Ther Targets, 10: 1-11. 